3 Ye Wu ${ }^{\mathrm{a}, \mathrm{b}, \mathrm{c}}$, Xiaoping $\mathrm{Chen}^{\mathrm{c}}$, Maohong Fan ${ }^{\mathrm{a}, \mathrm{d} *}$, Guodong Jiang ${ }^{\mathrm{a}}$, Yong Kong ${ }^{\mathrm{a}}$, Alan E.

\title{
Bland $^{\mathrm{e}}$
}

5 a Department of Chemical \& Petroleum Engineering, University of Wyoming,

6 Laramie, WY 82071, USA

$7 \quad$ School of Power Engineering, Nanjing University of Science \& Technology, Nanjing 8 210094, China.

$9 \quad{ }^{\mathrm{c}}$ School of Energy \& Environment, Southeast University, Nanjing 210096, China

$10{ }^{\mathrm{d}}$ School of Energy Resources, University of Wyoming, Laramie, WY 82071, USA

$11{ }^{\text {e}}$ Western Research Institute, Laramie, WY 82071, USA

\section{ABSTRACT}

The objective of this research was to develop composite $\mathrm{CO}_{2}$ sorbents for overcoming the shortcomings of the corresponding individual sorbents. The composite sorbents were synthesized with $\mathrm{K}_{2} \mathrm{CO}_{3}$, 3-aminopropyltriethoxysilane (APTES) and tetraethylorthosilicate (TEOS) and dried either with a supercritical or conventional technique. Comparative experiments demonstrated that supercritical fluid drying (SCFD) was better than conventional drying (CD) in preparing $\mathrm{CO}_{2}$ sorbents with more developed pore structure and thus higher $\mathrm{CO}_{2}$ sorption capacity. The composite sorbent prepared with SCFD was tested under various conditions for Corresponding author. E-mail: mfan@uwyo.edu; Phone: 1(307)766-5633 
their effects on $\mathrm{CO}_{2}$ sorption capacity. The optimal $\mathrm{K}: \mathrm{N}$ mole ratio for preparation of the composite sorbent and the reaction conditions for achieving the highest sorption capacity were obtained. In addition, the sorbent proved to be regenerable. Thus, supercritical drying is an effective technique for preparation of a promising composite $\mathrm{CO}_{2}$ sorbent.

Keywords: Post-combustion, $\mathrm{CO}_{2}$ capture, Sorption, Amine, $\mathrm{K}_{2} \mathrm{CO}_{3}$, Supercritical fluid drying

\section{INTRODUCTION}

Climate change reportedly associated with the increase in atmospheric $\mathrm{CO}_{2}$ concentration is one of the key challenges people have to face in the $21^{\text {st }}$ century [13]. Coal is one of the major energy resources in the world and it makes great contributions to gross domestic product [4]. For many years, combustion has been the dominant way of coal utilizations for different purposes including electricity generation, which has results in huge $\mathrm{CO}_{2}$ emissions into the atmosphere. Therefore, capturing the $\mathrm{CO}_{2}$ emitted from coal-fired power plants is necessary.

Several types of post-combustion $\mathrm{CO}_{2}$ capture technologies including sorption and membrane have been developed and great progresses have been made in these areas in recent years [5-8]. Sorption is a promising choice since the technology is more applicable to the flue gas which has high flow rates, low pressures and low $\mathrm{CO}_{2}$ concentrations [8]. The sorbents so far developed are purely either inorganic or 
organic. Supported $\mathrm{K}_{2} \mathrm{CO}_{3}$ and $\mathrm{Na}_{2} \mathrm{CO}_{3}$ are the representatives of inorganic sorbents and their $\mathrm{CO}_{2}$ capture reactions are:

$$
\begin{aligned}
& \mathrm{K}_{2} \mathrm{CO}_{3}+\mathrm{H}_{2} \mathrm{O}+\mathrm{CO}_{2} \leftrightarrow 2 \mathrm{KHCO}_{3} \\
& \mathrm{Na}_{2} \mathrm{CO}_{3}+\mathrm{H}_{2} \mathrm{O}+\mathrm{CO}_{2} \leftrightarrow 2 \mathrm{NaHCO}_{3} .
\end{aligned}
$$

The carbonates are inexpensive and widely available, and thus people are increasingly interested in using them for $\mathrm{CO}_{2}$ capture. Organic sorbents are based on amine compounds. People have loaded different types of amine compounds such as ethylenediamine and polyetherimide onto various supporting materials including titanium oxide and silica for syntheses of sorbents [9-11]. All the amine based $\mathrm{CO}_{2}$ sorption technologies are realized using either

$$
-\mathrm{NH}_{2}+\mathrm{H}_{2} \mathrm{O}+\mathrm{CO}_{2} \leftrightarrow\left[-\mathrm{NH}_{3}\right]^{+}\left[\mathrm{HCO}_{3}\right]
$$

or

$$
2\left(-\mathrm{NH}_{2}\right)+\mathrm{CO}_{2} \leftrightarrow\left[-\mathrm{NH}_{3}\right][-\mathrm{NHCOO}] .
$$

Both inorganic and organic sorbents have their own advantages and shortcomings. Inorganic sorbents are relatively inexpensive and stable but their $\mathrm{CO}_{2}$ sorption and desorption rates are slow. Organic sorbents typically have higher $\mathrm{CO}_{2}$ sorption capacities and are more dynamic during sorption and desorption processes than their inorganic counterparts $[12,13]$. For example, the $\mathrm{CO}_{2}$ sorption capacity of the polyethylenimine-loaded mesoporous carbons prepared by Wang and his coworkers was as high as $4.82 \mathrm{mmol}-\mathrm{CO}_{2} / \mathrm{g}$-sorbent [12]. However, the sorbent degradation or amine loss issue, which leads to the decreases in $\mathrm{CO}_{2}$ sorption capacities of organic sorbents during cyclic operations, has not been resolved [14]. To 
take the advantages of both types of sorbents and overcome their shortcomings, this research was deigned to develop a composite $\mathrm{CO}_{2}$ sorbent synthesized with an amine-containing compound and $\mathrm{K}_{2} \mathrm{CO}_{3}$. In addition, supercritical fluid and conventional drying approaches were compared for their effects on the performances of the resulting sorbents.

\section{EXPERIMENTS}

\section{Sorbent preparation and characterization}

The chemicals needed for preparing the sorbents used in this research were 3-aminopropyltriethoxysilane (APTES, ALDRICH, 99.0\%), Tetraethylorthosilicate (TEOS, ALDRICH, 98.0\%), ethanol $\left(\mathrm{C}_{2} \mathrm{H}_{5} \mathrm{OH}\right.$, Decon Labs, Inc., 200-proof), and pure $\mathrm{K}_{2} \mathrm{CO}_{3}$ (EMD Chemical Inc., 99.0\%). All the composite sorbent preparation processes proceeded through gel formation and drying processes. Gel formations were realized by mixing TEOS, 28.6 wt- $\% \mathrm{~K}_{2} \mathrm{CO}_{3}$ solution, APTES and ethanol with various mole ratios of $\mathrm{K}: \mathrm{N}$ at room temperature for 10 to 15 mins, depending on the mole ratio of the raw material. The quantities of TEOS and ethanol used in each sorbent preparation are constant. Conventional and supercritical methods were used to dry the gels. The conventional drying $(\mathrm{CD})$ was realized with an oven at $80^{\circ} \mathrm{C}$. Supercritical fluid drying(SCFD) started with aging wet gels at room temperature for $1 \mathrm{hr}$, followed by soaking them in pure $\mathrm{C}_{2} \mathrm{H}_{5} \mathrm{OH}$ three times to remove water at room temperature, drying them within a supercritical apparatus, a Speed SFE system 
(Applied Separations, Inc., Allentown, PA) under 10.0 MPa at room temperature to eliminate their $\mathrm{C}_{2} \mathrm{H}_{5} \mathrm{OH}$ until no noticeable $\mathrm{C}_{2} \mathrm{H}_{5} \mathrm{OH}$ exited from the supercritical apparatus, then dry them for $5 \mathrm{hrs}$ under the same pressure but at a little higher temperature, $31{ }^{\circ} \mathrm{C}$. The resulting sorbents from the conventional and supercritical fluid drying methods were named as CD-KN and SCFD-KN, respectively. In addition, for comparison purpose, a N-containing sorbent, designated as SCFD-N, was prepared with 3.75:7.5:75:14.75 mole ratio of TEOS, APTES, deionized water and ethanol and dewatered with SCFD technique.

The prepared KNs were characterized with different methods. A Micrometrics TriStar 3000V 6.04 A BET (Brunauer, Emmet, and Teller) analyzer was used for determination of the surface areas and the pore structures of KNs. Fourier transform infrared (FT-IR) spectra of SCFD-N (the N-containing sorbent synthesized with APTES and TEOS under supercritical fluid drying condition), $\mathrm{K}_{2} \mathrm{CO}_{3}$, and fresh and spent KNs were collected using a Thermo Nicolet Magna-IR 760 spectrometer. The morphological analyses of KNs were conducted using an FEI Quanta FEG 450 field-emission scanning electron microscope (SEM). In addition, a Physical Electronics PE5800 X-ray photoelectron spectrometer (XPS) was also used to characterize the sorbents.

\section{Apparatus and operation}

The experimental apparatus used in this research for $\mathrm{CO}_{2}$ sorption and desorption .has been reported elsewhere [15]. 0.1 0.5 $\mathrm{g} \mathrm{KN}$ was used for each 
sorption test, depending on the density of the sorbent. A $3 / 8$ in. quartz tube with a notch in it was used as the sorption/desorption reactor. Two pieces of quartz wool were placed at the two sides of the sorbent bed to hold sorbent during sorption and sorbent regeneration. Sorption temperatures in the reactor were controlled by a F21135 tube furnace (Barnstead International, Dubuque, IA). Water in the post-adsorption gas stream was eliminated by a water removal unit prior to $\mathrm{CO}_{2}$ analysis. $\mathrm{CO}_{2}$ concentrations of the inlet/outlet gas stream were measured by a ZRE infrared gas analyzer (Fuji Electric System Co., Ltd., Tokyo, Japan), and sorption and desorption data were collected with a DataChart 3000 recorder (Monarch Instrument, Inc., Amherst, NH).

Each sorption test was started with heating the reactor or adsorber loaded with a sorbent to $150{ }^{\circ} \mathrm{C}$ within a $500 \mathrm{ml} / \mathrm{min} \mathrm{N}_{2}$ environment to purge the moisture and $\mathrm{CO}_{2}$ in the reactor, followed by cooling the reactor to a desired sorption temperature, then passing a simulated flue gas stream with 1 vol- $\% \mathrm{CO}_{2}$ and 1 vol- $\% \mathrm{H}_{2} \mathrm{O}$. Each $\mathrm{CO}_{2}$ sorption test was ended when the outlet $\mathrm{CO}_{2}$ concentrations reached 1 vol- $\% \cdot \mathrm{CO}_{2}$ desorption was performed with pure $\mathrm{N}_{2}$ and stopped when the $\mathrm{CO}_{2}$ reading on the gas analyzer was zero. Each test was conducted three times under the same reaction condition, and the reported result at a given data point is the average value.

\section{RESULTS AND DISCUSSION}

\section{Characteristics of KNs}



ratios are presented in Figure 1. The FTIR spectra of pure amine and $\mathrm{K}_{2} \mathrm{CO}_{3}$, as shown in Figures 1a and 1b, respectively, well match with those reported in literature $[16,17]$. The strong bands at $1050 \mathrm{~cm}^{-1}$ in Figure $1 \mathrm{c}$ are due to the $\mathrm{C}-\mathrm{N}$ stretch of alkyl group or the presence of strained Si-O-Si bonds [18]. The bands at 690 880 $\mathrm{cm}^{-1}$ result from N-H stretches. With Figures $1 \mathrm{a}$ and $1 \mathrm{~b}$ being references, there are three new bands at $1585 \mathrm{~cm}^{-1}, 1506 \mathrm{~cm}^{-1}$ and $1380 \mathrm{~cm}^{-1}$ in Figures 1c and 1d. They

\section{Advantages of SCFD as a $\mathrm{CO}_{2}$ sorbent dewatering approach}

The elemental analyses of the two sorbents prepared with the same materials, 10 mL TEOS, $10 \mathrm{~mL} 26.8 \mathrm{wt}-\% \mathrm{~K}_{2} \mathrm{CO}_{3}, 30 \mathrm{~mL}$ APTES, and $20 \mathrm{~mL}$ ethanol (TEOS: $\mathrm{K}: \mathrm{N}$ : ethanol $=3.75: 5: 11.25: 14.75)$ ] but by two different drying methods were measured with XPS. The $\mathrm{K}$ and $\mathrm{N}$ concentrations of the CD-KN were found to be 3.5 mmol-K/g-KN and $5.51 \mathrm{mmol}-\mathrm{N} / \mathrm{g}-\mathrm{KN}$, respectively, while the corresponding values of SCFD-KN are $3.98 \mathrm{mmol}-\mathrm{K} / \mathrm{g}-\mathrm{KN}$ and $6.59 \mathrm{mmol}-\mathrm{N} / \mathrm{g}-\mathrm{KN}$.

The pore volume and BET surface areas of the CD-KN are $0.02 \mathrm{~cm}^{3} / \mathrm{g}$ and 6.90 $\mathrm{m}^{2} / \mathrm{g}$, respectively, much smaller than those corresponding values of SCFD-NK, 0.176 $\mathrm{cm}^{3} / \mathrm{g}$ and $72.2 \mathrm{~m}^{2} / \mathrm{g}$, while the pore size of the CD-KN, $15.0 \mathrm{~nm}$, is much larger than 
that of SCFD-KN, $3.1 \mathrm{~nm}$. The higher pore volume, and surface area, and smaller pore size of SCFD-NK are all beneficial to the improvement of its $\mathrm{CO}_{2}$ sorption capacity. The SEM images of the same CD-KN and SCFD-KN (Figure 2) demonstrate that the SCFD-KN is more unfragmented and porous than the CD-KN. Therefore, SCFD is an effective method for the improvement of the pore structure of the sorbent. The $\mathrm{CO}_{2}$ sorption profiles of the CD-KN and SCFD-KN are shown in Figure 3. The $\mathrm{CO}_{2}$ sorption capacity of the SCFD-KN, 2.03 mmol- $\mathrm{CO}_{2} / \mathrm{g}-\mathrm{KN}$, is much higher than that $\left(1.17 \mathrm{mmol}-\mathrm{CO}_{2} / \mathrm{g}-\mathrm{KN}\right)$ achieved with the $\mathrm{CD}-\mathrm{KN}$. The better $\mathrm{CO}_{2}$ sorption performance of the SCFD-KN should be attributed to its superior structure, including higher BET surface area and larger pore volume as well as smaller pore size and diffusion for the gas phase, its netlike assembly, and higher $\mathrm{K}$ and $\mathrm{N}$ concentrations.

In addition, the nill-experiments were conducted. The $\mathrm{CO}_{2}$ sorption capacity of the pure amine-silica sorbent is $1.49 \mathrm{mmol} \mathrm{CO} / \mathrm{g}$ sorbent while that of pure $\mathrm{K}_{2} \mathrm{CO}_{3}$ is $0.041 \mathrm{mmol} \mathrm{CO}_{2} / \mathrm{g}$ sorbent [21]. Therefore, the $\mathrm{CO}_{2}$ sorption performance of the composite sorbent is better than individual sorbents and a simple mixture of them.

\section{Factors affecting the performance of SCFD-KNs}

\section{$K$ and $N$ loadings}

The observed $\mathrm{CO}_{2}$ sorption capacities of the composite sorbents are mainly determined by their $\mathrm{K}$ and $\mathrm{N}$ loadings or concentrations. Theoretically, all the $\mathrm{K}$ and $\mathrm{N}$ on the surface of a given sorbent can be used for $\mathrm{CO}_{2}$ sorption via $\mathrm{R} 1$ and $\mathrm{R} 3$. 
However, the theoretical sorption capacities are not reachable because the molecular sizes of the sorption products are almost always larger than those of sorbents. Furthermore, the size of $\left[-\mathrm{NH}_{3}\right]^{+}\left[-\mathrm{NHCO}_{2}\right]^{-}$formed with $\mathrm{R} 3$ is larger than that of $\mathrm{KHCO}_{3}$ generated from R1. Therefore, it is desired that more $\mathrm{K}$ in form of $\mathrm{K}_{2} \mathrm{CO}_{3}$ is loaded on SCFD-KN with a given surface area to maximize the $\mathrm{CO}_{2}$ sorption capacities of the composite sorbents. However, the activation energy of $\mathrm{CO}_{2}$ sorption with $-\mathrm{NH}_{2}\left(E_{R 3}, 49.0 \mathrm{~kJ} / \mathrm{mol}\right)$, is smaller than that with $\mathrm{K}_{2} \mathrm{CO}_{3}\left(E_{R 1}, 71.9 \mathrm{~kJ} / \mathrm{mol}\right)$ $[22,23]$. Based on

$$
\frac{k_{R 1}}{k_{R 3}}=\frac{A_{R 1}}{A_{R 3}} e^{\frac{E_{R 3}-E_{R R}}{83114 T}}=\frac{A_{R 1}}{A_{R 3}} e^{-\frac{22900}{8316 T}}=\frac{A_{R 1}}{A_{R 3}} e^{\frac{-2.75434}{T}}
$$

where $k_{R 1}$ and $k_{R 3}$ are the rate constants of the forward reactions of R1 and R3, respectively, while $A_{R 1}$ and $A_{R 3}$ are the corresponding pre-exponential factors of Arrhenius forms of the forward reactions of $\mathrm{R} 1$ and $\mathrm{R} 3$, at $40{ }^{\circ} \mathrm{C}(313 \mathrm{~K})$,

$$
\frac{k_{R l}}{k_{R 3}}=\frac{A_{R l}}{6,632.9 \times A_{R 3}}
$$

Thus it is very likely that the $\mathrm{CO}_{2}$ sorption rate of $\mathrm{R} 3$ is larger than that with $\mathrm{R} 1$ assuming that $A_{R 1}$ and $A_{R 3}$ are too different. In addition, the reaction orders of all the associated chemicals in both $\mathrm{R} 1$ and $\mathrm{R} 3$ affect the rates of $\mathrm{CO}_{2}$ sorption with the sorbent. The total $\mathrm{CO}_{2}$ sorption rate of the composite sorbent can be expressed as

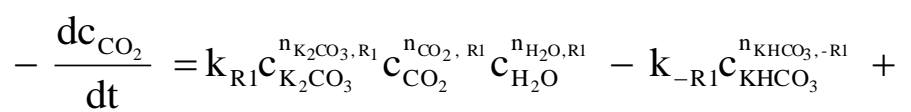

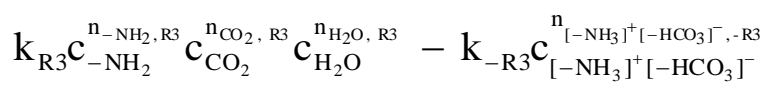

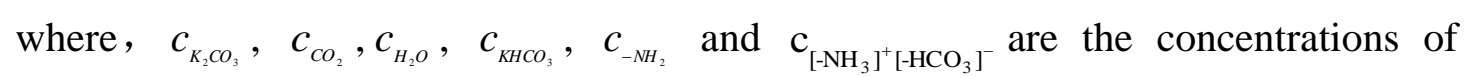
$\mathrm{K}_{2} \mathrm{CO}_{3}, \mathrm{KHCO}_{3}, \mathrm{CO}_{2}, \mathrm{H}_{2} \mathrm{O},-\mathrm{NH}_{2}$, and $\left(-\mathrm{NH}_{3}{ }^{+}\right)\left(-\mathrm{HCO}_{3}{ }^{-}\right)$at any sorption time, $\mathrm{t}$, 
respectively, $k_{R 1}, k_{-R 1}, k_{R 3}$ and $k_{-R 3}$ are the corresponding rate constants of forward and reverse processes of R1 and R3, while $n_{K_{2} \mathrm{CO}_{3}, \mathrm{R} 1}, \quad n_{\mathrm{CO}_{2}, \mathrm{R} 1}, n_{\mathrm{H}_{2}, \mathrm{O}, \mathrm{R} 1}, n_{\mathrm{KHCO}_{3},-R \mathrm{R}}$, $n_{-\mathrm{NH}_{2}, \mathrm{R3}}, \quad n_{\mathrm{CO}_{2}, \mathrm{R3}}, \quad n_{\mathrm{H}_{2}, \mathrm{R}, \mathrm{R3}}$ and $\mathrm{n}_{\left[-\mathrm{NH}_{3}\right]^{+}\left[-\mathrm{HCO}_{3}\right]^{-},-\mathrm{R} 3}$, are the reaction orders with respect to $\mathrm{K}_{2} \mathrm{CO}_{3}, \mathrm{CO}_{2}, \mathrm{H}_{2} \mathrm{O}, \mathrm{KHCO}_{3},-\mathrm{NH}_{2}, \mathrm{CO}_{2}, \mathrm{H}_{2} \mathrm{O}$ and $\left(-\mathrm{NH}_{3}{ }^{+}\right)\left(-\mathrm{HCO}_{3}{ }^{-}\right)$in the reversible $\mathrm{R} 1$ and R3. The loadings of $\mathrm{K}$ and $\mathrm{N}$ of SCFD-KNs affect the pre-exponential factors of the Arrhenius equations and thus the rate constants, and the concentration terms in E3, which eventually affect the total $\mathrm{CO}_{2}$ sorption capacities of the composite sorbents as presented in Figure 4. The $\mathrm{CO}_{2}$ sorption capacity changes significantly within the tested $\mathrm{K}: \mathrm{N}$ ratio range, and reaches the highest value, 2.83 mmol- $\mathrm{CO}_{2} / \mathrm{g}-\mathrm{KN}$ when the $\mathrm{K}: \mathrm{N}$ ratio is $6: 12$ or $1: 2$. High $\mathrm{K}$ and $\mathrm{N}$ loadings did not necessarily lead to high $\mathrm{CO}_{2}$ sorption capacity due to the decrease in surface area and pore-clogging, as indicated in Table 1 . The lower the loadings of $\mathrm{K}$ and $\mathrm{N}$ on the surface of the SCFD-KN, the higher the BET surface area and pore volume of the sorbent are and the lower the average pore size of the sorbent is. The sorbent with the lowest $\mathrm{K}(0.024$ mole $\mathrm{K})$ and $\mathrm{N}(0.034$ mole $\mathrm{N})$ loadings has the highest BET surface area and pore volume and the lowest pore size. Neither $\mathrm{K}$ and $\mathrm{N}$ loadings nor the pore characteristics can be used as the sole indicator of $\mathrm{CO}_{2}$ sorption performances of SCFD-KNs. The $\mathrm{CO}_{2}$ sorption capacity of SCFD-KN is the integral effect of both pore characteristics and $\mathrm{K}$ as well as $\mathrm{N}$ loadings. Therefore, the SCFD-KN with the highest $\mathrm{CO}_{2}$ sorption capacity (TEOS: $\mathrm{K}$ : $\mathrm{N}$ : ethanol $=3.75: 6: 12: 14.75$ ) is chosen for further studies. 


\section{Temperature}

The $\mathrm{CO}_{2}$ sorption processes of SCFD-KN or the forward reactions of $\mathrm{R} 1$ and $\mathrm{R} 3$ are relatively sensitive to temperatures because neither $E_{R 1}$ nor $E_{R 3}$ is too low. However, $\mathrm{K}$ based $\mathrm{CO}_{2}$ sorption is more sensitive to temperature than $\mathrm{N}$ based sorption because of

$$
\frac{d\left[k_{R 1} / k_{R 3}\right]}{d T}=\frac{A_{R 1}}{A_{R 3}} e^{-\frac{2,75434}{T}} \times \frac{2,754.34}{T^{2}}>0 .
$$

In other words, an increase in temperature will accelerate $\mathrm{CO}_{2}$ sorption with $\mathrm{K}$ to a higher degree than with N. On the other hand,

$$
\begin{array}{ll}
\frac{\partial \ln K_{R 1}}{\partial T}=\frac{\Delta H_{R 1}}{R T^{2}}<0 & \text { or } \mathrm{T} \uparrow \propto \mathrm{q}_{\mathrm{CO}_{2}, \mathrm{R} 1} \downarrow \\
\frac{\partial \ln K_{R 3}}{\partial T}=\frac{\Delta H_{R 3}}{R T^{2}}<0 & \text { or } \mathrm{T} \uparrow \propto \mathrm{q}_{\mathrm{CO}_{2}, \mathrm{R} 3} \downarrow
\end{array}
$$

and

$$
\frac{\partial\left[K_{R 1} / K_{R 3}\right]}{\partial T}=\frac{\partial\left[E X P\left(\Delta G_{R 3}-\Delta G_{R 1}\right) / R T\right]}{\partial T}=e^{-\frac{2.40 .559}{T}} \times \frac{2,405.59}{T^{2}}>0
$$

where $K_{R 1}$ and $K_{R 3}$ represent the equilibrium constants of R1 and R3, $\Delta \mathrm{G}_{\mathrm{Rl}}\left(\approx \Delta \mathrm{G}_{\mathrm{Rl}}^{0}=-36.6 \mathrm{~kJ} / \mathrm{mol}\right) \quad[15]$ and $\Delta \mathrm{G}_{\mathrm{R} 3}\left(\approx \Delta \mathrm{G}_{\mathrm{R} 3}^{0}=-50.6 \mathrm{~kJ} / \mathrm{mol}\right) \quad[24,25]$ are the Gibbs free energy changes of R1 and R3, respectively. E5, E6 and E7 indicate that the increase in temperature should negatively affect the $\mathrm{CO}_{2}$ sorption capacities via both $\mathrm{R} 1$ and $\mathrm{R} 3$, and thus the total $\mathrm{CO}_{2}$ capacity of SCFD-KN, as shown in the 50-80 ${ }^{\circ} \mathrm{C}$ range in Figure 5, although $K_{R 1}$ decreases with $\mathrm{T}$ relatively slower than $K_{R 3}$ does. However, the total $\mathrm{CO}_{2}$ sorption capacity of SCFD-KN actually increases with $\mathrm{T}$ in the $25-50{ }^{\circ} \mathrm{C}$ range, as shown in Figure 5, which is probably due to more water condensations on the surface of the sorbent at lower temperatures. The liquid water resulting from condensation could plug the pores especially small pores of the sorbent, 
increase mass transfer resistance, and thus decrease the $\mathrm{CO}_{2}$ sorption of the sorbent.

\section{Moisture}

Enough $\mathrm{H}_{2} \mathrm{O}$ is necessary for $\mathrm{K}$ based $\mathrm{CO}_{2}$ sorption and the increase in $\mathrm{CO}_{2}$ sorption capacity of $\mathrm{N}$ based sorbents, according to R1, R3 and R4. The concentrations of water in the inlet gas have significant effects on $\mathrm{CO}_{2}$ sorption capacities, as demonstrated in Figure 6. Without the presence of $\mathrm{H}_{2} \mathrm{O}, \mathrm{K}_{2} \mathrm{CO}_{3}$ cannot react with $\mathrm{CO}_{2}$ or $\mathrm{R} 1$ cannot proceed, while $-\mathrm{NH}_{2}$ in SCFD-KN still can react with $\mathrm{CO}_{2}$ through $\mathrm{R} 4$ whose $\Delta G_{R 4}^{0}$ and $E_{R 4}$ are $-25.0 \mathrm{~kJ} / \mathrm{mol}$ and $14.6 \mathrm{~kJ} / \mathrm{mol}$, respectively [22,24]. Therefore, the sorbent still shows $\mathrm{CO}_{2}$ sorption capacity of 0.72 mmol- $\mathrm{CO}_{2} / \mathrm{g}-\mathrm{KN}$. When moisture was introduced, R1, R3 and R4 occurred simultaneously, although R1 and R3 definitely compete for $\mathrm{H}_{2} \mathrm{O}$. At lower temperatures, it is likely that $\mathrm{R} 3$ should dominate and be the main $\mathrm{H}_{2} \mathrm{O}$ consuming reaction since R3 not only has the lower activation energy but also has the higher Gibbs free energy change, as discussed early. However, according to E4 and E7, the role $\mathrm{R} 1$ plays in the overall $\mathrm{CO}_{2}$ sorption increases with temperature, and various pathways or species including $\left(-\mathrm{NH}_{3}{ }^{+}\right)\left(\mathrm{OH}^{-}\right), \mathrm{NH}_{3}{ }^{+}, \quad\left(-\mathrm{NH}_{3}{ }^{+}\right)\left(-\mathrm{NHCOO}^{-}\right)$and $\left(-\mathrm{NH}_{3}{ }^{+}\right)\left(\mathrm{HCO}_{3}^{-}\right)$exist with $\mathrm{CO}_{2}$ sorption by $-\mathrm{NH}_{2}$ within a moisture-containing environment [8]. Therefore, the selectivity of the three overall or apparent reactions in the presence of $\mathrm{H}_{2} \mathrm{O}$ becomes complicated but can be studied if the thermodynamic and kinetic parameters of R1, R3 and R4 are available either through experiments or by literature. The study can be used not only for predicting the effect of $\mathrm{H}_{2} \mathrm{O}$ on 
selectivity but also for optimizing the reaction conditions and thus sorption capacity. The highest $\mathrm{CO}_{2}$ sorption capacity, $3.02 \mathrm{mmol} / \mathrm{g}-\mathrm{KN}$, was achieved with $c_{H_{2}, 0,0}: c_{c_{2}, 0}$ mole ratio being 1.2 , higher than stoichiometric value, $1 . \mathrm{CO}_{2}$ has low solubility in $\mathrm{H}_{2} \mathrm{O}$ and overdosing $\mathrm{H}_{2} \mathrm{O}$ to some degree can increase the quantity of $\mathrm{CO}_{2}$ in the quasi-liquid layer [21] between bulk gas and solid phases in the heterogeneous $\mathrm{CO}_{2}$ sorption system, and thus increase in $\mathrm{CO}_{2}$ sorption capacity.

\section{Gas flow rate}

The effect of gas flow rate on $\mathrm{CO}_{2}$ sorption capacity was evaluated and the results are presented in Figure 7. Under the given conditions, $\mathrm{CO}_{2}$ sorption capacity of the SCFD-KN sorbent increases with gas flow rate. $\mathrm{CO}_{2}$ sorption capacities of the $\mathrm{KN}$ sorbent increase from 2.15 to $3.32 \mathrm{mmol}-\mathrm{CO}_{2} / \mathrm{g}-\mathrm{KN}$ as gas flow rate increases from $300 \mathrm{ml} / \mathrm{min}$ to $700 \mathrm{ml} / \mathrm{min}$. This fact can be explained with the following relationship that Tuwati, et al [21] obtained with the sorption equation set by Yan, et al [26].

$$
\frac{\partial q_{\mathrm{CO}_{2}}}{\partial Q}=\frac{Q t}{k_{y} m}\left[\frac{c_{\mathrm{CO}_{2}}}{c_{\mathrm{CO}_{2,0}}-c_{C O_{2}}}\right]^{\frac{k_{1} c_{C_{2}, 0}}{Q}}\left[2-\frac{k_{Y} c_{\mathrm{CO}_{2}, 0}}{Q} \ln \frac{c_{\mathrm{CO}_{2}}}{c_{\mathrm{CO}_{2,0}, 0}-c_{C O_{2}}}\right]
$$

where $q_{\mathrm{CO}_{2}}$ is $\mathrm{CO}_{2}$ sorption capacity, $Q$ is gas flow rate, $k_{y}$ is the sorption kinetic rate constant, $m$ is the mass of SCFD-KN, $t$ is the sorption time, and $c_{c o s_{3}, 0}$ and $c_{C O_{2}}$ are the $\mathrm{CO}_{2}$ concentrations in inlet and outlet gases, respectively. When $\frac{k_{\gamma} c_{\mathrm{CO}_{2}, 0}}{Q} \ln \frac{c_{\mathrm{CO}_{2}}}{c_{\mathrm{CO}_{2,0}}-c_{\mathrm{CO}_{2}}}$ is smaller than 2, then $q_{\mathrm{CO}_{2}}$ increases with $Q$, which is the case observed with this research. The degree of $\mathrm{CO}_{2}$ sorption capacity increase with gas 
284 flow rate is due to the dominance of the decrease in $\left[\frac{c_{C_{2}}}{c_{C O_{2,0}}-c_{C O_{2}}}\right]^{\frac{k_{1} c_{C_{2}, 0}}{Q}}$ in the right side 285 of E8, which results from the increase of $Q$ in $\frac{k_{Y} c_{C_{2,0}, 0}}{Q}$.

\section{Regeneration}

The $\mathrm{CO}_{2}$ sorption capacity of the regenerated SCFD-KN is important since any applicable sorbents need to perform well with multiple $\mathrm{CO}_{2}$ sorption and desorption tests. Figure 8 demonstrates the working capacities of the sorbent over $10 \mathrm{CO}_{2}$ separation cycles conducted with 1 vol- $\% \mathrm{CO}_{2}$ gas mixture under the condition of sorption at $40{ }^{\circ} \mathrm{C}$ and desorption at $150{ }^{\circ} \mathrm{C}$. The working capacities of the SCFD-KN sorbent during the cyclic $\mathrm{CO}_{2}$ separation were kept at $\sim 2.8 \mathrm{mmol}_{-} \mathrm{CO}_{2} / \mathrm{g}-\mathrm{KN}$, indicating that the sorbent is stable over multiple cycles. Its stability was also evaluated by comparing the FTIR spectra (Figure 9) of the fresh sorbent to that of the regenerated sorbent. The characteristic bands of the fresh sorbent are the same as those of the regenerated sorbent, indicating that SCFD is an advanced technology to prepare not only capable but also regenerable composite $\mathrm{CO}_{2}$ sorbent.

\section{CONCLUSION}

A kind of alternative $\mathrm{KN}$-based $\mathrm{CO}_{2}$ sorbent, dried with supercritical method, has been synthesized and evaluated for its performance on separation of $\mathrm{CO}_{2}$ from flue gas. Sorption tests were carried out under different conditions including those temperatures, $\mathrm{H}_{2} \mathrm{O}$ concentration and flow rates rarely tested on lab-scale by other 
researchers but important to the applications of any $\mathrm{CO}_{2}$ sorbents. The $\mathrm{CO}_{2}$ sorption capacities of SCFD-KN sorbent achieved with 1 vol-\% gas mixture is higher than $\mathrm{CD}-\mathrm{KN}$ sorbent due to the difference in densities and structures. Moreover, $\mathrm{KN}$ sorbent is regenerable based on the good repeatability of $\mathrm{CO}_{2}$ sorption capacities obtained during multi-cycle $\mathrm{CO}_{2}$ sorption-desorption tests. The equipment requirements for separation of $\mathrm{CO}_{2}$ with $\mathrm{KN}$ sorbent should be less challenging than those for other $\mathrm{CO}_{2}$ separation technologies because $\mathrm{KN}$ sorbent can be regenerated at $150^{\circ} \mathrm{C}$, lower than those of conventional $\mathrm{K}_{2} \mathrm{CO}_{3}$-based sorbent. Correspondingly, the capital energy needs for the $\mathrm{CO}_{2}$ separation technology should be rather low. The operation costs of $\mathrm{KN}$-based $\mathrm{CO}_{2}$ separation process can be considerably reduced due to its high $\mathrm{CO}_{2}$ sorption capacity, fast $\mathrm{CO}_{2}$ sorption and desorption kinetics as well as the good regenerative ability of the sorbent.

There is still room for the technology to be further improved. For example, the BET surface area and pore volume of $\mathrm{KN}$ sorbent could be improved for enhancement of $\mathrm{CO}_{2}$ sorption capacity because the $\mathrm{KN}$ sorbent used in this research has lower BET surface area and pore volume than the majority of other organic sorbents, although its $\mathrm{CO}_{2}$ sorption capacity is higher than theirs. Finally but importantly, all the parameters in the proposed kinetic model need to be established using thermodynamic and kinetic theories as well as experiments for optimization of the $\mathrm{CO}_{2}$ separation technology and eventually other Amine based $\mathrm{CO}_{2}$ separation processes. The $\mathrm{CO}_{2}$ conversion ratio of Amine is lower, and it's significant to find Amine-loaded organic chemicals with better $\mathrm{CO}_{2}$ sorption performance. 


\section{ACKNOWLEDGMENT}

The supports for the research include the Department of Energy, California Energy Commission, and Wyoming Clean Coal Program in the U.S., and the High Technology Research and Development Program, Natural Science Foundation and Scholarship Council and National Natural Science Foundation in China.

\section{NOMENCLATURE}

$k_{R 1}, k_{-R 1}, k_{R 3}, k_{-R 3}$ the corresponding rate constants of forward and reverse processes of $\mathrm{R} 1$ and $\mathrm{R} 3, \mathrm{~min}^{-1}$

$A_{R 1}, \quad A_{R 3}$ the corresponding factors of Arrhenius forms of the forward reactions of R1 and $\mathrm{R} 3, \mathrm{~min}^{-1}$

$c_{K_{2} \mathrm{OO}_{3}}, \quad c_{\mathrm{CO}_{2}}, c_{\mathrm{H}_{2} \mathrm{O}}, \quad c_{\mathrm{KHCO}_{3}}, \quad c_{-\mathrm{NH}_{2}}, \mathrm{c}_{\left.\left.\mathrm{[-NH}_{3}\right]^{+}-\mathrm{HCO}_{3}\right]^{-}}$the concentrations of $\mathrm{K}_{2} \mathrm{CO}_{3}, \mathrm{KHCO}_{3}$,

$\mathrm{CO}_{2}, \mathrm{H}_{2} \mathrm{O},-\mathrm{NH}_{2}$, and $\left(-\mathrm{NH}_{3}{ }^{+}\right)\left(-\mathrm{HCO}_{3}{ }^{-}\right), \quad \mathrm{mol} / \mathrm{cm}^{3}$

$c_{c o, 0,0}$, the $\mathrm{CO}_{2}$ concentrations in inlet gas, $\mathrm{mol} / \mathrm{cm}^{3}$

$\mathrm{t}$ the sorption time, min

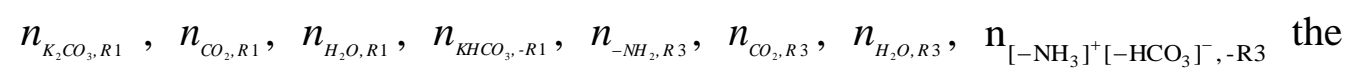

reaction orders with respect to $\mathrm{K}_{2} \mathrm{CO}_{3}, \mathrm{CO}_{2}, \mathrm{H}_{2} \mathrm{O}, \mathrm{KHCO}_{3},-\mathrm{NH}_{2}, \mathrm{CO}_{2}, \mathrm{H}_{2} \mathrm{O}$ and

$\left(-\mathrm{NH}_{3}^{+}\right)\left(-\mathrm{HCO}_{3}^{-}\right)$in the two reversible $\mathrm{R} 1$ and $\mathrm{R} 3$.

$K_{R 1}, K_{R 3}$ the equilibrium constants of R1 and R3,

$\Delta \mathrm{G}_{\mathrm{R} 1}$ and $\Delta \mathrm{G}_{\mathrm{R} 3}$ the Gibbs free energy changes of $\mathrm{R} 1$ and $\mathrm{R} 3, \mathrm{~kJ} / \mathrm{mol}$

$q_{c \alpha_{2}} \mathrm{CO}_{2}$ sorption capacity, $\mathrm{mmolCO}_{2} / \mathrm{g}$ sorbent

$Q$ gas flow rate, $\mathrm{mL} / \mathrm{min}$ 
$m$ the mass of SCFD-KN, $\mathrm{g}$

350 Abbreviations

351 APTES 3-aminopropyltriethoxysilane

352 TEOS tetraethylorthosilicate

353 SCFD supercritical fluid drying approach

354 CD conventional drying approach

$355 \mathrm{KN}$ the composite sorbent

356 SCFD-KN the composite sorbents dried with supercritical fluid drying method

357 SCFD-N a amine-silica sorbent dried with supercritical fluid drying method

358 CD-KN the composite sorbents dried with conventional approach

359

360

\section{REFERENCE}

361

362

363

364

365

366

[1] S. Bakker, H. Coninck, H. Groenenberg, Progress on including CCS projects in the CDM: Insights on increased awareness, market potential and baseline methodologies, Int. J. Green Gas Cont. 4 (2010) 321-326.

[2] H. Coninck, J. Stephens, B. Metz, Global learning on carbon capture and storage: A call for strong international cooperation on CCS demonstration, Energy Policy. 37 (2009) 2161-2165.

367 [3] L.C. Skinner, S. Fallon, C. Waelbroeck, E. Michel, S. Barker, Ventilation of the 368 deep southern ocean and deglacial $\mathrm{CO}_{2}$ rise, Science. 328 (2010) 1147-1151. 
369

370

371

372

373

374

375

376

377

378

379

380

381

382

383

384

385

386

387

[4] W.M. Budzianowski, Modelling of $\mathrm{CO}_{2}$ content in the atmosphere until 2300: influence of energy intensity of gross domestic product and carbon intensity of energy, Int. J. Global Warming. 5 (2013) 1-17.

[5] A. Brunetti, F. Scura, G. Barbieri, Membrane technologies for $\mathrm{CO}_{2}$ separation, Journal of Membrane Sci. 359 (2010) 115-125.

[6] B.P. Mandal, A.K. Biswas, S.S. Bandyopadhyay, Absorption of carbon dioxide into aqueous blends of 2-amino-2-methyl-1-propanol and diethanolamine, Chem. Eng. Sci. 58 (2003) 4137-4144.

[7] Y. Liang, D.P. Harrison, R.P. Gupta, Carbon dioxide capture using dry sodium-based sorbents, Energy Fuel. 18 (2004) 569-575.

[8] L. He, M. Fan, B. Dutcher, Dynamic separation of ultradilute $\mathrm{CO}_{2}$ with a nanoporous amine-based sorbent, Chem. Eng. J. 189-199 (2012) 13-23.

[9] O. Al-Azzawi, C.M. Hofmann, G.A. Baker, S.N. Baker. Nanosilica-supported polyethoxyamines as low-cost, reversible carbon dioxide sorbents, J. Colloid. Interf. Sci. 385 (2012) 154-159.

[10]A. Aboudheir, P. Tontiwachwuthikul, A. Chakma, Kinetics of the reactive absorption of carbon dioxide in high $\mathrm{CO}_{2}$-loaded, concentrated aqueous monoethanolamine solutions, Chem. Eng. Sci. 58 (2003) 5195-5210.

[11]S. Choi, J.H. Drese, P. Eisenberger, Application of Amine-Tethered Solid Sorbents for Direct $\mathrm{CO}_{2}$ Capturefrom the Ambient Air, Environ Sci Technol. 45 (2011) 2420-2427.

[12]J. Wang, H. Chen, Carbon dioxide capture using polyethylenimine-loaded mesoporous carbons, J Environ Sci. 25 (2013) 124-132. 
[13]H. Yang, Z. Xu, M. Fan, Progress in carbon dioxide separation and capture: A 393 review, J Environ Sci. 20 (2008) 14-27.

394

[14]C. Gouedard, D. Picq, F. Launay, P.L. Carrette, Amine degradation in $\mathrm{CO}_{2}$ 395

[15]B. Zhang, M. Fan, A. Bland, $\mathrm{CO}_{2}$ separation by a new solid K-Fe sorbent, Energy Fuel. 25 (2011) 1919-1925. http://www.chemistry.ccsu.edu/glagovich/teaching/316/ir/table.html.

400

401

402

403

404

405

406

407

408

409

410

411

412

413

[17]A. Chowdhury, J. Bould, Nano-powders of $\mathrm{Na}_{0.5} \mathrm{~K}_{0.5} \mathrm{NbO}_{3}$ made by a sol-gel method, J Nanopart Res. 12 (2010) 209-215.

[18]B. Dutcher, M. Fan, Use of Nanoporous FeOOH as a catalytic support for $\mathrm{NaHCO}_{3}$ decomposition aimed at reduction of energy requirement of $\mathrm{Na}_{2} \mathrm{CO}_{3} / \mathrm{NaHCO}_{3}$ based $\mathrm{CO}_{2}$ separation technology, J. Phys. Chem. C. 115 (2011) 15532-15544.

[19]L.Ć. Ivana, K.Ć. Jugoslav, Biodiesel synthesis using $\mathrm{K}_{2} \mathrm{CO}_{3} / \mathrm{Al}-\mathrm{O}-\mathrm{Si}$ aerogel catalysts, J. Serb. Chem. Soc. 75 (2010) 789-801.

[20]L. Dei, P. Baglioni, Aging effects on ammonium carbonate/acetone solutions and cleaning of Works of Art, Stud Conserv. 41(1996) 9-18.

[21]A. Tuwati, M. Fan, A.G. Russell, J. Wang, H. Dacosta, New $\mathrm{CO}_{2}$ sorbent synthesized with nanoporous $\mathrm{TiO}(\mathrm{OH})_{2}$ and $\mathrm{K}_{2} \mathrm{CO}_{3}$, Energy Fuel. 27(2013) 7628-7636.

[22]J.M. Plaza, D.V. Wagener, G.T. Rochelle, Modeling $\mathrm{CO}_{2}$ capture with aqueous 
monoethanolamine, Int. J. Green Gas Cont. 4 (2010) 161-166.

415

[23]S. Shen, X. Feng, R. Zhao, U.K. Ghosh, A. Chen, Kinetic study of carbon dioxide absorption with aqueous potassium carbonate promoted by arginine, Chem. Eng. J. 222 (2013) 478-487.

[24]H. Xie, Y. Zhou, Y. Zhang, J.K. Johnson, Reaction Mechanism of monoethanolamine with $\mathrm{CO}_{2}$ in aqueous solution from molecular modeling, $\mathrm{J}$. Phys. Chem. A. 114 (2010) 11844-11852.

[25]Y. Liu, L. Zhang, S. Watanasiri, Representing vapor-liquid equilibrium for an aqueous MEA- $\mathrm{CO}_{2}$ system using the electrolyte nonrandom-two-liquid model, Ind. Eng. Chem. Res. 38 (1999) 2080-2090.

[26]G. Yan, T. Viraraghavan, M. Chen, A new model for heavy metal removal in a biosorption column, Adsorpt. Sci. Technol. 19 (2001) 25-43.

\section{Figure list}

Figure 1 FT-IR spectra of SCFD-N, $\mathrm{K}_{2} \mathrm{CO}_{3}$ and two SCFD-KNs.

Figure 2 SEM images of typical CD-KN and SCFD-KN samples (a: CD-KN; b: SCFD-KN).

Figure 3 The typical $\mathrm{CO}_{2}$ sorption-sorption profiles of two $\mathrm{KN}$ sorbents prepared with conventional and SCFD methods [Sorption (Gas composition: $\mathrm{CO}_{2}-1.0$ vol-\%; $\mathrm{H}_{2} \mathrm{O}-$ 1.0 vol-\%); Gas flow rate: $0.3 \mathrm{~L} / \mathrm{min}$; Temperature: $\left.40{ }^{\circ} \mathrm{C}\right)$, Desorption $\left(\mathrm{N}_{2}\right.$ flow rate: $0.3 \mathrm{~L} / \mathrm{min}$; temperature: $\left.150{ }^{\circ} \mathrm{C}\right)$ ].

Figure 4 Effect of $\mathrm{K}: \mathrm{N}$ mole ratios on the $\mathrm{CO}_{2}$ sorption performances of SCFD-KNs (Gas flow rate: $0.5 \mathrm{~L} / \mathrm{min} ; \mathrm{CO}_{2}$ concentration: 1.0 vol- $\% ; \mathrm{H}_{2} \mathrm{O}$ concentration: 1.0 vol-\%; Temperature: $40{ }^{\circ} \mathrm{C}$ ).

Figure 5 Effect of temperature on the $\mathrm{CO}_{2}$ sorption performance of a SCFD-KN (Gas flow rate: $0.5 \mathrm{~L} / \mathrm{min} ; \mathrm{CO}_{2}$ concentration: 1.0 vol- $\% ; \mathrm{H}_{2} \mathrm{O}$ concentration: 1.0 vol-\%). 
Figure 6 Effect of $\mathrm{H}_{2} \mathrm{O}$ concentration on the $\mathrm{CO}_{2}$ sorption performance of a SCFD-KN (Gas flow rate: $0.5 \mathrm{~L} / \mathrm{min} ; \mathrm{CO}_{2}$ concentration: 1.0 vol-\%; Temperature: 40 $\left.{ }^{\circ} \mathrm{C}\right)$.

450

451

452

453

454

455

456

457

458

459

460

461

462

463

464

465

466

467

468

469

470

471

472

473

474

475

476

477

478

479

480

481

482

483

484

485

486

487

488

489

Figure 7 Effect of gas flow rate on the $\mathrm{CO}_{2}$ sorption performance of a SCFD-KN ( $\mathrm{CO}_{2}$ concentration: 1.0 vol- $\% ; \mathrm{H}_{2} \mathrm{O}$ concentration: 1.0 vol- $\%$; Temperature: $40{ }^{\circ} \mathrm{C}$ ).

Figure 8 Multi sorption-desorption performance of a SCDF-KN sorbent [Sorption (Gas composition: $\mathrm{CO}_{2}-1.0$ vol- $\%$; $\mathrm{H}_{2} \mathrm{O}-1.0$ vol- $\%$ ); Gas flow rate: $0.5 \mathrm{~L} / \mathrm{min}$; Temperature: $\left.40{ }^{\circ} \mathrm{C}\right)$, Desorption $\left(\mathrm{N}_{2}\right.$ flow rate: $0.5 \mathrm{~L} / \mathrm{min}$; Temperature: $\left.\left.150{ }^{\circ} \mathrm{C}\right)\right]$.

Figure 9 FT-IR spectra of a SCFD-KN sorbent before and after 10 sorption-desorption cycles [Sorption (Gas composition: $\mathrm{CO}_{2}-1.0$ vol-\%; $\mathrm{H}_{2} \mathrm{O}-1.0$ vol-\%); Gas flow rate: $0.5 \mathrm{~L} / \mathrm{min}$; Temperature: $\left.40{ }^{\circ} \mathrm{C}\right)$, Desorption $\left(\mathrm{N}_{2}\right.$ flow rate: $0.5 \mathrm{~L} / \mathrm{min}$; temperature: $\left.\left.150{ }^{\circ} \mathrm{C}\right)\right]$. 


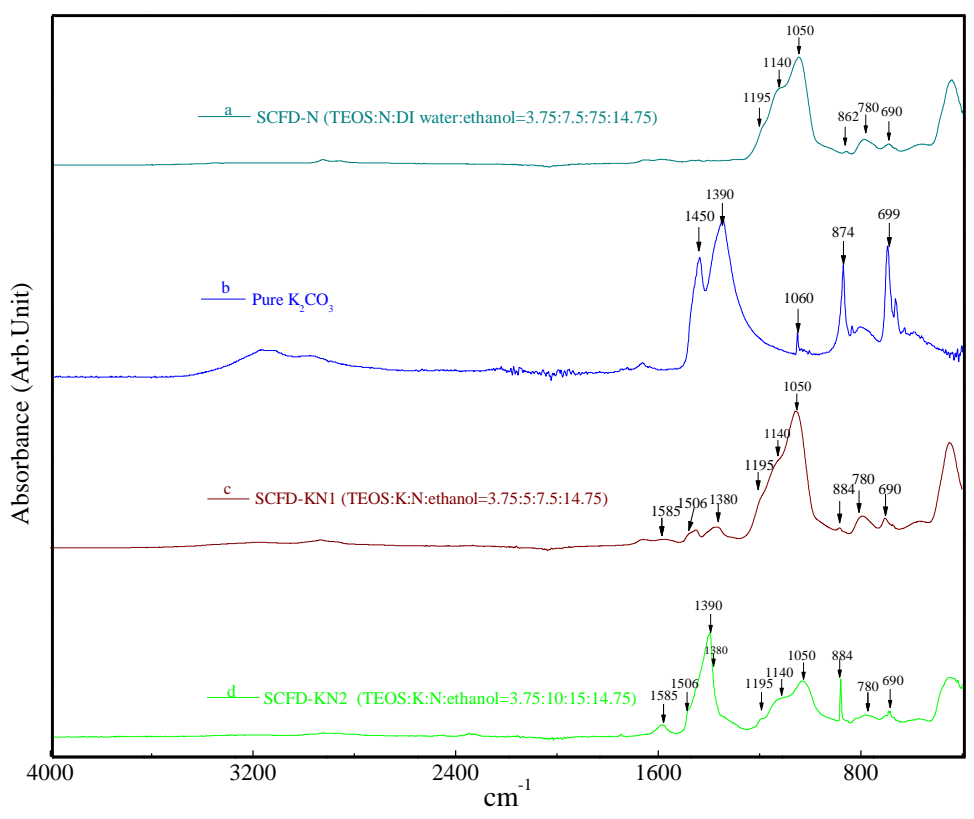

491 Figure 1 FTIR spectra of SCFD-N, $\mathrm{K}_{2} \mathrm{CO}_{3}$ and two SCFD-KNs.

492

493

494

495

496

497

498

499

500

501

502

503

504

505

506

507

508

509

510

511

512

513

514

515

516

517

518 


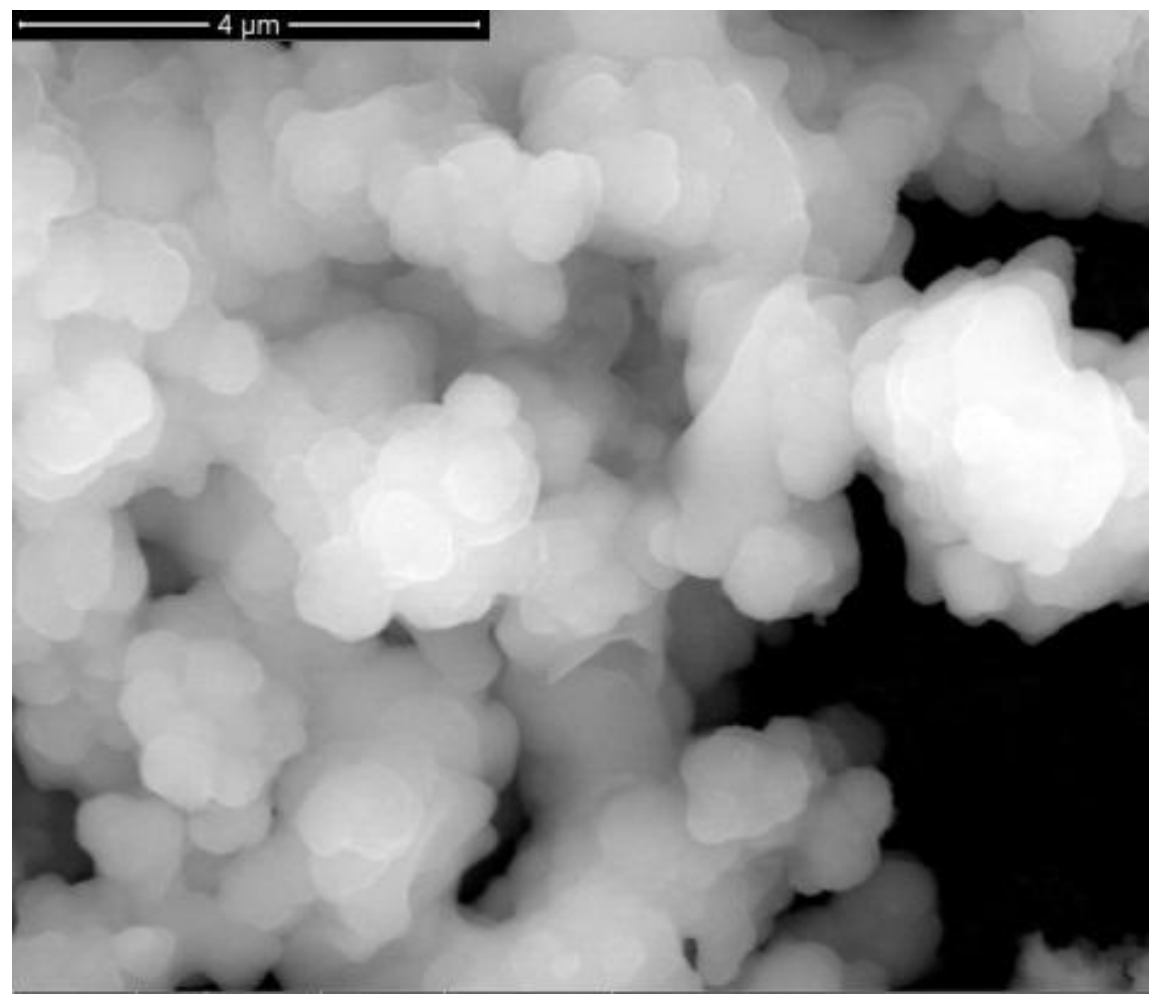

(a)

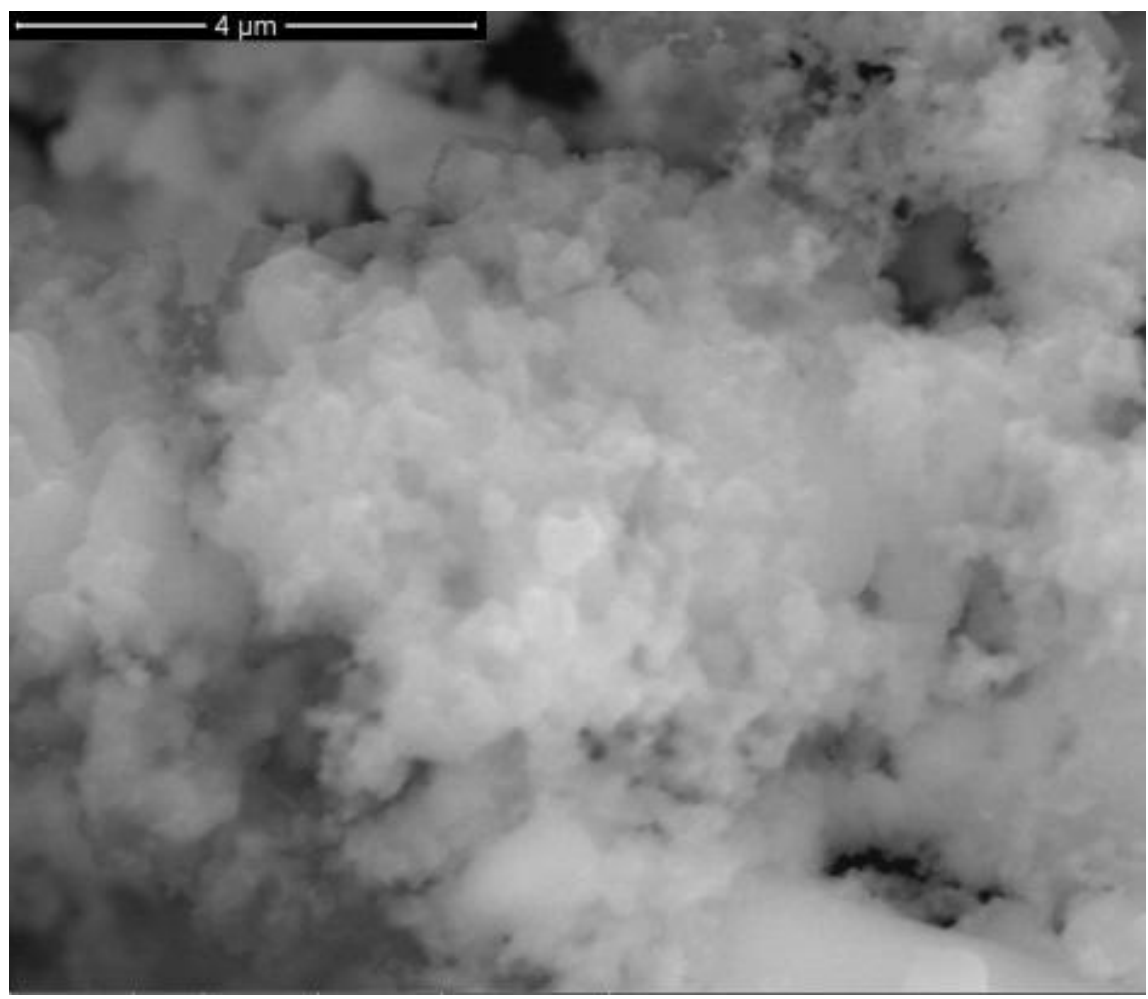

523 Figure 2 SEM images of typical CD-KN and SCFD-KN samples (a: CD-KN; b: 524 SCFD-KN). 
526

527

528

529

530

531

532

533

534

535

536

537

538

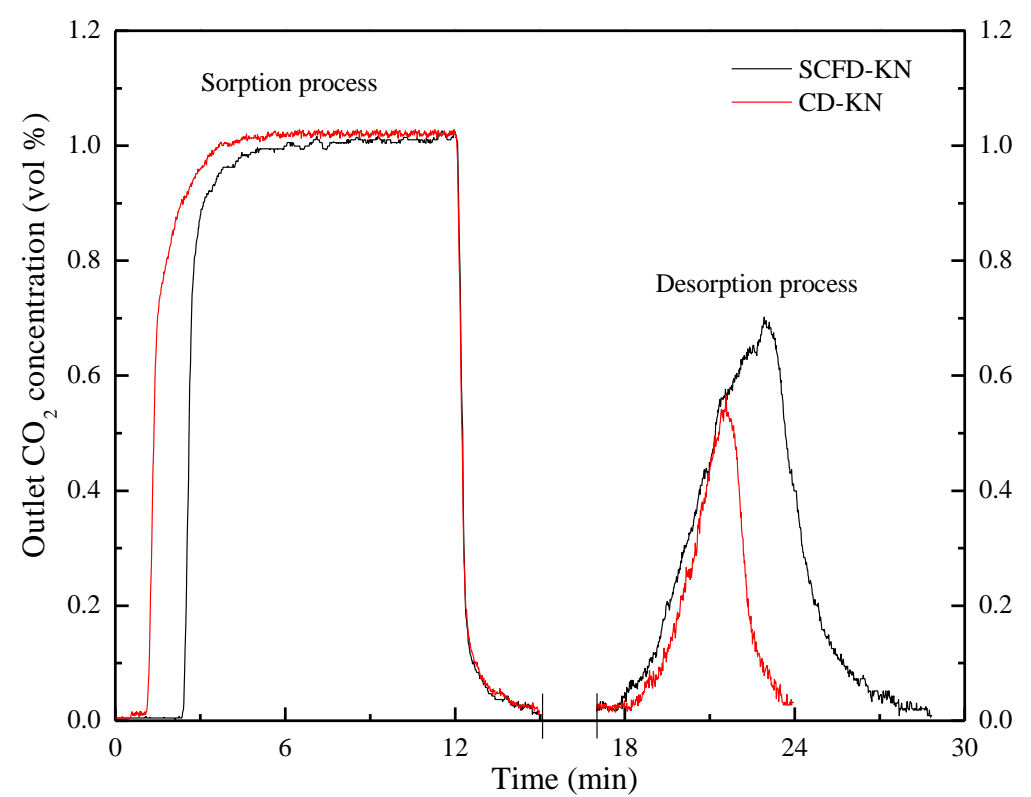

Figure 3 The typical $\mathrm{CO}_{2}$ sorption-sorption profiles of two $\mathrm{KN}$ sorbents prepared with conventional and SCFD methods [Sorption (Gas composition: $\mathrm{CO}_{2}-1.0$ vol-\%; $\mathrm{H}_{2} \mathrm{O}-$ 1.0 vol-\%); Gas flow rate: $0.3 \mathrm{~L} / \mathrm{min}$; Temperature: $\left.40{ }^{\circ} \mathrm{C}\right)$; Desorption $\left(\mathrm{N}_{2}\right.$ flow rate: $0.3 \mathrm{~L} / \mathrm{min}$; temperature: $150{ }^{\circ} \mathrm{C}$ )]. 


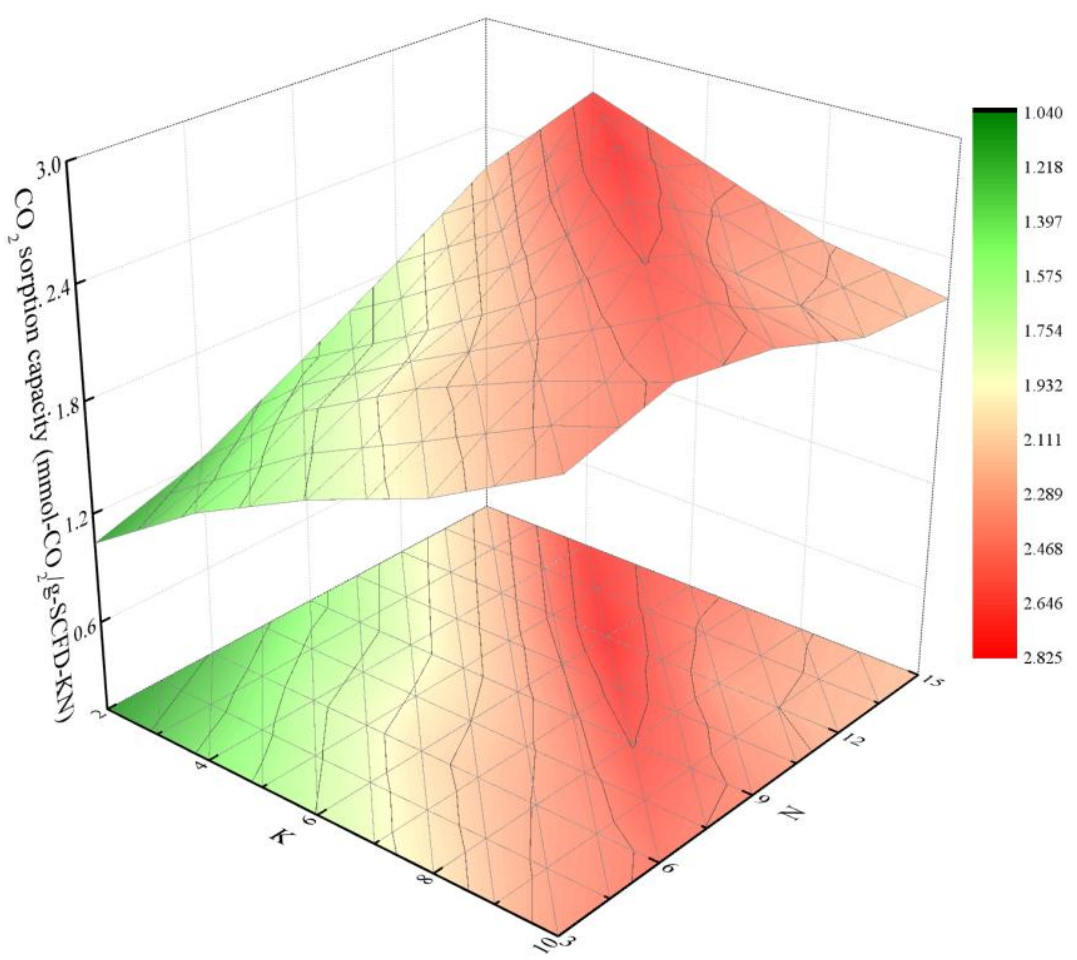

540 Figure 4 Effect of $\mathrm{K}: \mathrm{N}$ mole ratios on the $\mathrm{CO}_{2}$ sorption performances of SCFD-KNs

541 (Gas flow rate: $0.5 \mathrm{~L} / \mathrm{min} ; \mathrm{CO}_{2}$ concentration: 1.0 vol- $\% ; \mathrm{H}_{2} \mathrm{O}$ concentration: 1.0

542 vol-\%; Temperature: $40{ }^{\circ} \mathrm{C}$ ).

543

544

545

546

547

548

549

550

551

552

553 


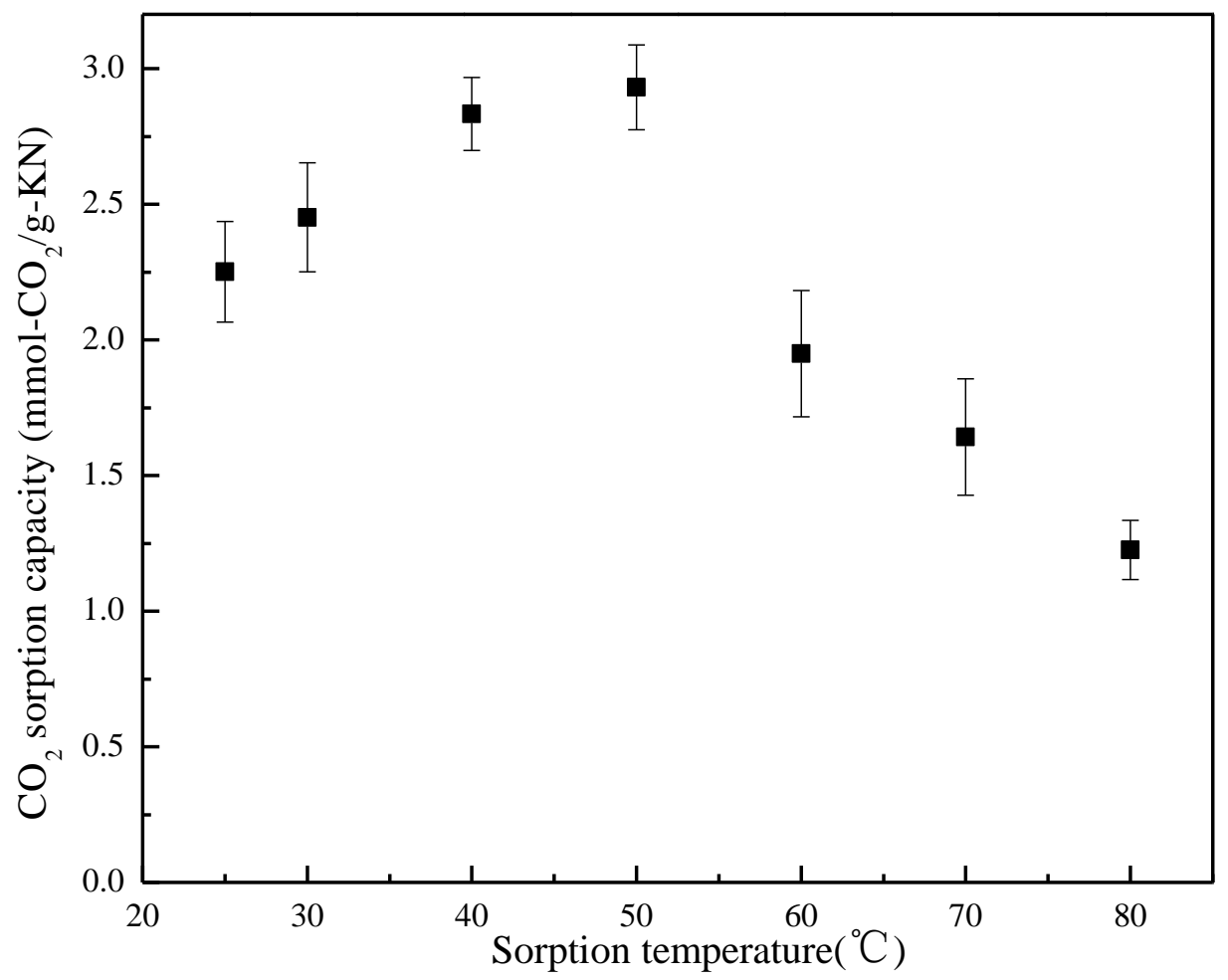

555 Figure 5 Effect of temperature on the $\mathrm{CO}_{2}$ sorption performance of a SCFD-KN (Gas

556 flow rate: $0.5 \mathrm{~L} / \mathrm{min} ; \mathrm{CO}_{2}$ concentration: 1.0 vol- $\% ; \mathrm{H}_{2} \mathrm{O}$ concentration: 1.0 vol- $\%$ ).

557

558

559

560

561

562 


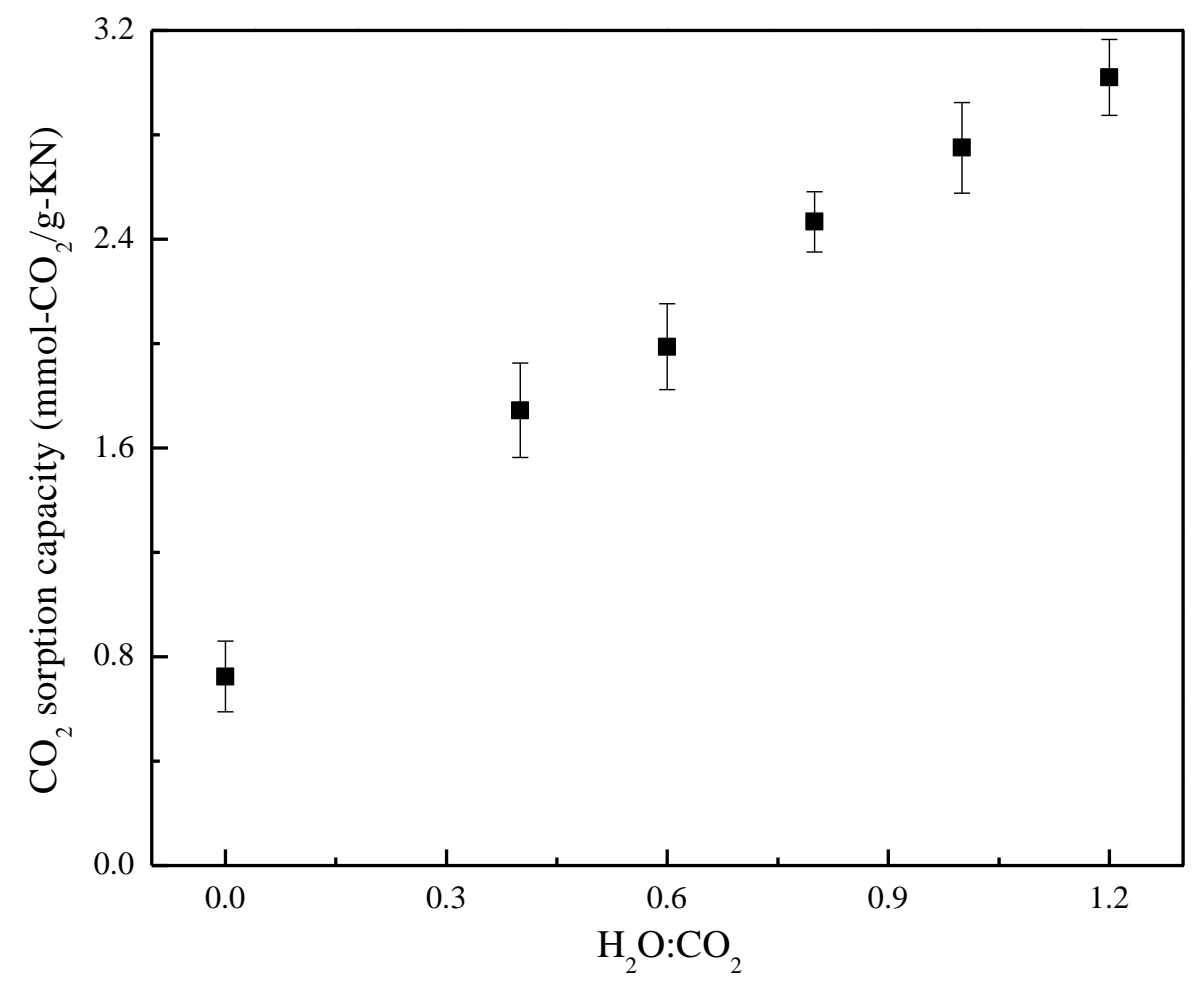

563

564 Figure 6 Effect of $\mathrm{H}_{2} \mathrm{O}$ concentration on the $\mathrm{CO}_{2}$ sorption performance of a 565 SCFD-KN (Gas flow rate: $0.5 \mathrm{~L} / \mathrm{min} ; \mathrm{CO}_{2}$ concentration: 1.0 vol-\%; Temperature: 40 $566{ }^{\circ} \mathrm{C}$ ). 


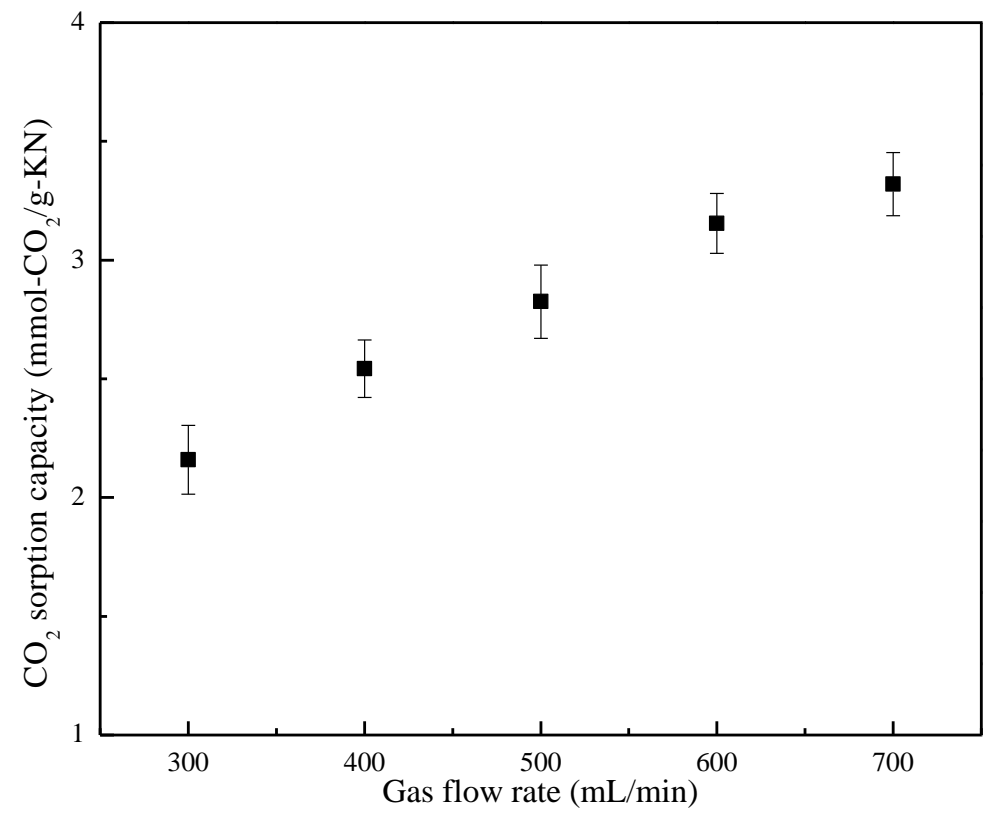

579

580 Figure 7 Effect of gas flow rate on the $\mathrm{CO}_{2}$ sorption performance of a SCFD-KN

581 ( $\mathrm{CO}_{2}$ concentration: 1.0 vol- $\% ; \mathrm{H}_{2} \mathrm{O}$ concentration: 1.0 vol- $\%$; Temperature: $40{ }^{\circ} \mathrm{C}$ ).

582

583

584

585

586

587

588

589

590

591

592

593

594 


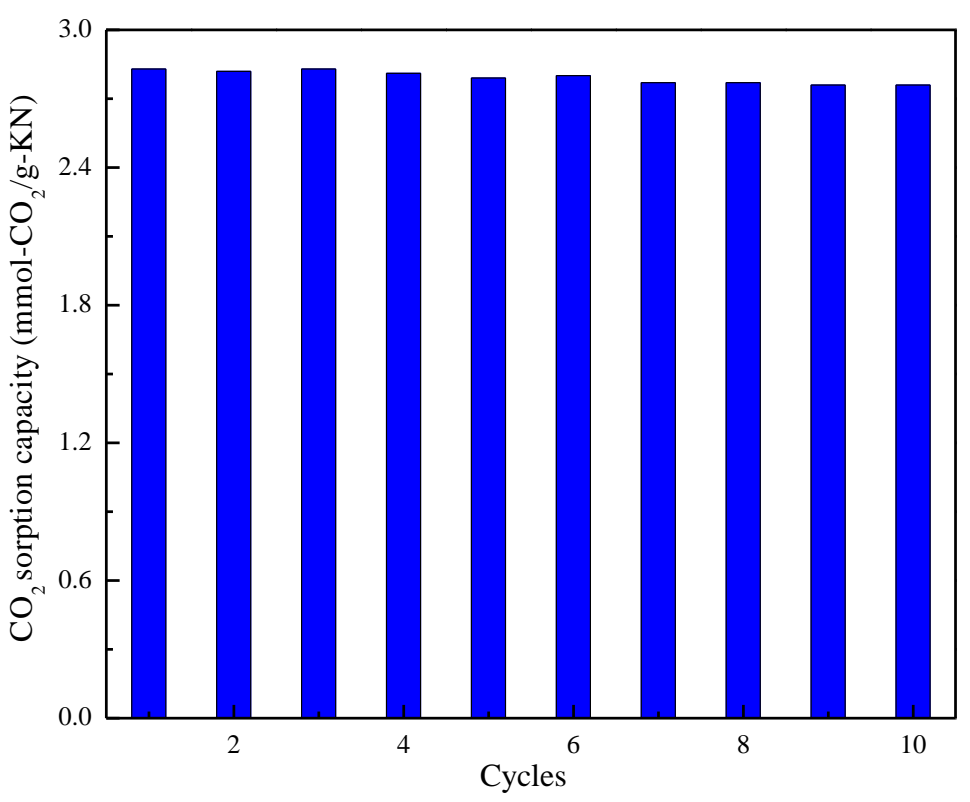

595

596

597

598

599

600

601

602

603

604

605

606

607

608

609

610

611

612

613

614

615

616 


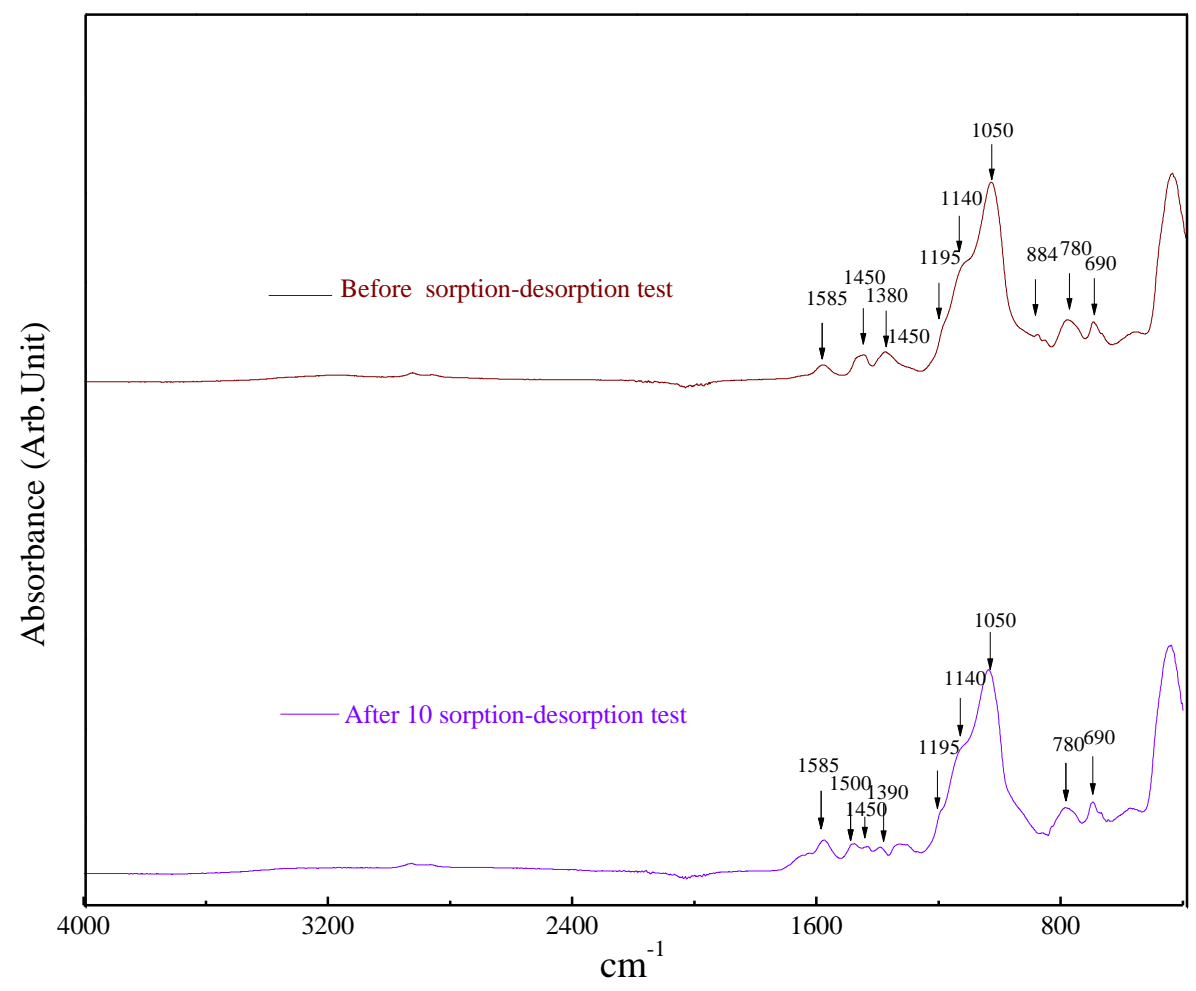

617

618 Figure 9 FTIR spectra of a SCFD-KN sorbent before and after 10 sorption-desorption 619 cycles.

620

621

622

623

624

625

626

627

628

629

630

631

632

633

634

635

636

637

638

639

640

641

642 
644

Sample

Surface area Pore volume Pore size

\begin{tabular}{ccccc} 
Mole ratio of K:N & Drying method & $\left(\mathrm{m}^{2} / \mathrm{g}\right)$ & $\left(\mathrm{cm}^{3} / \mathrm{g}\right)$ & $(\mathrm{nm})$ \\
\hline $2: 3$ & SCFD & 110.224 & 0.254 & 2.075 \\
$4: 6$ & SCFD & 94.347 & 0.216 & 2.441 \\
$6: 9$ & SCFD & 88.784 & 0.201 & 2.594 \\
$6: 12$ & SCFD & 64.745 & 0.154 & 3.538 \\
$8: 12$ & SCFD & 46.214 & 0.112 & 4.879 \\
$10: 15$ & SCFD & 21.874 & 0.072 & 7.758
\end{tabular}

645

646

647

648

649

650

651

652

653

654

655 